\title{
High variability in SSU rDNA gene copy number among planktonic foraminifera revealed by single-cell qPCR
}

\author{
Tamara Milivojević $\mathbb{D}^{1,2}$, Shirin Nurshan Rahman ${ }^{1}$, Débora Raposo $\mathbb{D}^{1}$, Michael Siccha ${ }^{1}$, Michal Kucera ${ }^{1}$ and Raphaël Morard ${ }^{1 凶}$
}

(c) The Author(s) 2021

Metabarcoding has become the workhorse of community ecology. Sequencing a taxonomically informative DNA fragment from environmental samples gives fast access to community composition across taxonomic groups, but it relies on the assumption that the number of sequences for each taxon correlates with its abundance in the sampled community. However, gene copy number varies among and within taxa, and the extent of this variability must therefore be considered when interpreting community composition data derived from environmental sequencing. Here we measured with single-cell qPCR the SSU rDNA gene copy number of 139 specimens of five species of planktonic foraminifera. We found that the average gene copy number varied between of $\sim 4000$ to $\sim 50,000$ gene copies between species, and individuals of the same species can carry between $\sim 300$ to more than 350,000 gene copies. This variability cannot be explained by differences in cell size and considering all plausible sources of bias, we conclude that this variability likely reflects dynamic genomic processes acting during the life cycle. We used the observed variability to model its impact on metabarcoding and found that the application of a correcting factor at species level may correct the derived relative abundances, provided sufficiently large populations have been sampled.

ISME Communications; https://doi.org/10.1038/s43705-021-00067-3

\section{INTRODUCTION}

The goal of community ecology is to understand the role of biotic and abiotic factors that control the variation of community composition in time and space [1]. This requires sampling over spatial, temporal and environmental gradients, across which the constituent taxa are identified and their abundance enumerated. This poses numerous challenges, such as the difficulty to cover the full range of organism sizes, in the open ocean spanning twelve orders of magnitude [2], with a single sampling protocol [3], or the difficulty to taxonomically identify each collected specimen in the plankton that spans the entire tree of life [4]. A potentially powerful workaround to these limitations is to analyse DNA in bulk environmental samples. By sequencing short informative DNA barcodes one can potentially produce an exhaustive inventory of all organisms in a given sample. No time-consuming sorting of single specimens and expert taxonomic assessment is involved in the process, providing fast access to large amounts of data. Indeed, this approach has been successfully applied to assess diversity in the sunlit ocean [5], abyssal plains [6], neotropical soils [7], for monitoring of pollution impacts [8] and a broad range of other settings and applications [9].

Metabarcoding, however, is not free of limitations. It needs robust experimental design [10] and only provides information on relative proportion (compositionality) of sequences, without knowing how they relate to the actual proportion of individuals in the community [11]. The choice of the amplified fragment is always a compromise between the target group (taxonomic coverage) and the specificity (taxonomic resolution), and the identification of species relies on the availability of curated reference databases that link the sequences to known taxa [12]. The small subunit ribosomal DNA (SSU rDNA) is a widely used gene for metabarcoding, because it is present in all eukaryotes and well documented in reference databases [13]. The SSU rDNA is a multi-copy gene, whose gene copy number has been studied in many other protist groups, such as dinoflagellates, chlorophytes, ciliates and stramenopiles [14-17]. There is a broad agreement that the gene copy number correlates with body size when considering organisms spanning several orders of magnitude in body length (See Figure W3 in [5]). The relationship to body size is clearly visible across the full range of cell and body sizes of eukaryotes, but it is less obvious at the scale of size variability within a single taxa or clade. For example, ciliates harbour much higher gene copy number than other protists compared to their size $[15,18]$ and small sized ciliates taxa can have higher gene copy number than large sized ones [19], contradicting the general rule of correlation between size and gene copy number. This is important, because differences in gene copy number that cannot be related to body size may bias community composition data obtained from metabarcoding studies in unpredictable directions [20].

In this study, we assess the number of gene copies of planktonic foraminifera, a group of mixotrophic protists with calcite shells that are widely used as paleoceanographic proxies [21]. They have pervasive cryptic diversity [22-24] but their biological diversity is well constrained and limited, as confirmed by metabarcoding studies $[25,26]$. The molecular diversity of benthic foraminifera

${ }^{1}$ MARUM Center for Marine Environmental Sciences, University of Bremen, Leobener Strasse, 28359 Bremen, Germany. ${ }^{2}$ Max Planck Institute for Marine Microbiology, Bremen, Germany. ${ }^{\infty}$ email: rmorard@marum.de

Received: 28 July 2021 Revised: 7 October 2021 Accepted: 14 October 2021

Published online: 30 October 2021 
has been extensively documented with metabarcoding [6, 27-31] and previous work showed that the number of SSU rDNA gene copies varied between $\sim 10000$ and $\sim 30000$ between species [32]. However, the relationship to cell size has not been constrained because the analyses were based on pooled samples. Establishing a calibration between the number of gene copies and the number of individuals will increase the amount of information that could be extracted from metabarcoding data. Specifically, it will allow us to translate proportions of taxa represented by reads in metabarcodes to the proportions of individuals as recorded by census counts. In this way metabarcoding observations can be linked to the wealth of existing data on species occurrence and abundance, collectively allowing us to constrain the horizontal and vertical distribution of species and their relation to abiotic factors. This knowledge is necessary to interpret observations of changes in community composition in fossil assemblages [33]. To this end, we applied single-cell real time qPCR to characterize the variability in SSU rDNA gene copy number in five species of planktonic foraminifera and evaluate the relationship of gene copy number with individual size.

\section{MATERIAL AND METHODS \\ Sample collection}

All specimens of this study were sourced from our collection of cryopreserved specimens available at the University of Bremen. Our collection contains specimens recovered from multi-net samples collected between 0 and 700 metres using nets with mesh sizes from 63 to $200 \mu \mathrm{m}$. The specimens isolated from the plankton were cleaned with brushes and transferred onto cardboard slides and air-dried before being stored at $-20^{\circ} \mathrm{C}$ or $-80^{\circ} \mathrm{C}$ until further processing. Further details of the collection procedures are described in [34]. We selected specimens of the morphological species Globigerinella siphonifera, Trilobatus sacculifer, Neogloboquadrina pachyderma, Neogloboquadrina dutertrei and Globigerinita glutinata collected during the cruises MSM66, M113/2, M124 and M133 at six stations. Specimens were identified under a Zeiss V8 stereomicroscope and those selected were photographed using a KEYENCE VHX 6000 digital microscope in standard position to produce focus stacked $2.5 \mathrm{D}$ images to quantify individual cell volumes (see below). After imaging, each specimen was transferred into individual $1.5 \mathrm{ml}$ tube with $50 \mu \mathrm{l}$ of DOC lysis buffer for single cell DNA extractions. Every 24th tube was left empty to serve as negative control.

\section{DNA extraction}

The DOC lysis buffer [34] was chosen for this study because it dissolves entirely the shell of foraminifera and does not require purification steps that would lead to the loss of genetic material. The tubes were first sonicated in an ultrasonic bath for three minutes to break the shell and facilitate the digestion of the entire cellular material. Then, the samples were vortexed and shortly centrifuged to homogenize the buffer before being heated and vortexed at $60^{\circ} \mathrm{C}$ for $1 \mathrm{~h}$ in an Eppendorf Thermomixer. Every $20 \mathrm{~min}$ the tubes were taken out of the thermomixer, vortexed and shortly centrifuged to ensure the homogeneity of the buffer throughout the digestion process. In case there were still cellular material visible after the end of digestion, the tubes were sonicated for two minutes again and the extraction was repeated until all material was dissolved. After the extractions were finished, the samples were stored at $4{ }^{\circ} \mathrm{C}$ until further processing.

\section{Volumetric data}

Volumetric data of each specimen were extracted from the $2.5 \mathrm{D}$ pictures using a custom MATLAB script. The focus-stacked images taken with magnifications ranging between $\times 200$ and $\times 500$ yielded elevation maps with effective voxel side lengths between 2.05 and $0.82 \mu \mathrm{m}$. Foraminifera outline detection was performed by active contour segmentation and where necessary additionally manually edited when attachments, discolorations or shadows hampered automatic segmentation. Test volume was approximated by complementing the measured volume of the visible upper part of the specimen above mid outline height by an artificial spherical lower part. This artificial volume had the shape of the foraminifera outline at average outline height and decreased its outline parabolically until converging with height zero at the location of the centroid of the foraminifera outline height cross section (See Fig. S1).

\section{Primer selection}

For accurate quantification of gene copy numbers it is recommended to use fragments of a length not exceeding $300 \mathrm{bp}$, optimally $50-150 \mathrm{bp}$ long [35]. For foraminifera, the $37 \mathrm{~F}(38-132 \mathrm{bp})$ fragment qualifies but unfortunately not all planktonic foraminifera species can be successfully amplified using a single pair of primers. This is due to a 1-3 nucleotide difference on the position of the forward S14F1 primer between the spinose clade and other foraminifera mutations [36]. Alternatively, the pair of primer S18F-S19F that amplifies the fragment 45E-47F (179-312 bp) works for all planktonic foraminifera species but its length makes it a less ideal choice for $\mathrm{QPCR}$ amplification.

To assess the impact of both potential issues, we amplified the $37 \mathrm{~F}$ region by use of the primer pair S14F1-S15r2 for the species Neogloboquadrina pachyderma and the primer pair $\mathrm{S} 14 \mathrm{p}-\mathrm{S} 15 \mathrm{r} 2$ for the species Trilobatus sacculifer. We also amplified the region $45 \mathrm{E}-47 \mathrm{~F}$ using the primer pair S18F-S19F for both species. We compared the results by doing a linear correlation to assess the scalability of the results with both markers and proceeded with the pair S18F-S19F for quantification in all species (see results).

\section{PCR test}

DNA extraction success was assessed with normal PCR using the S18F-S19F primer pair. Preparation of PCR master mix was handled under a sterilized UV hood. Master mix was composed as follows: $8.35 \mu \mathrm{l}$ of Milli-Q water, $3 \mu \mathrm{l}$ of $5 x$ Phusion Green HF buffer (x1.00 final concentration), $0.75 \mu$ of $50 \mathrm{mM}$ $\mathrm{MgCl} 2(2.5 \mu \mathrm{mol} / \mu \mathrm{l}), 0.45 \mu \mathrm{l}$ of $100 \%$ DMSO $(0.75 \mu \mathrm{mol} / \mathrm{ml}), 0.30 \mu \mathrm{l}$ of dNTP $\operatorname{mix}(0.20 \mu \mathrm{mol} / \mathrm{ml}), 0.5 \mu \mathrm{l}$ of forward primer $(0.33 \mu \mathrm{mol} / \mathrm{ml}), 0.5 \mu \mathrm{l}$ of reverse primer $(0.33 \mu \mathrm{mol} / \mathrm{ml})$ and $0.15 \mu \mathrm{l}$ of Phusion Green Hot Start II HF $2 \mathrm{U} / \mu \mathrm{l}$ polymerase $(0.02 \mathrm{U} / \mu \mathrm{l})$ and $1 \mu \mathrm{l}$ of DNA extraction. The DNA was amplified with an initial denaturation at $98^{\circ} \mathrm{C}$ for $30 \mathrm{~s}$, followed by 35 cycles at $98^{\circ} \mathrm{C}$ for $10 \mathrm{~s}, 65^{\circ} \mathrm{C}$ for $30 \mathrm{~s}$ and $72^{\circ} \mathrm{C}$ for $30 \mathrm{~s}$ and $10 \mathrm{~min}$ of final extension at $72^{\circ} \mathrm{C}$. Success in amplification was checked with agarose gel electrophoresis and only samples displaying strong single bands were retained for further analyses.

\section{Standards curve for qPCR}

Prior to the quantification of gene copy numbers, standard curves were developed for each species. Positive PCR products obtained during the previous step were purified using the QIAquick PCR purification kit (QIAGEN) and the DNA concentration of the products were measured using the Quantus Fluorometer with Promega QuantiFluor dsDNA System kit following manufacturer's instructions. The number of gene copies were calculated from the formula of [17]:

molecules $/ \mu \mathrm{l}=\mathrm{DNA}$ concentration $(\mathrm{g} / \mu \mathrm{l}) /($ fragment length $\times 660)$

$$
\times 6.022 \times 10^{23}
$$

We used the $\mathrm{PFR}^{2}$ database [37] to establish the size of the fragments $45 \mathrm{E}-47 \mathrm{~F}$ for every species and the fragment $37 \mathrm{~F}$ for the $\mathrm{N}$. pachyderma and $T$. sacculifer (It includes the hypervariable region and the conserved flanking region). For the region $45 \mathrm{E}-47 \mathrm{~F}$ the fragment sizes were the following: 385 bp for Neogloboquadrina pachyderma, 362 bp for Trilobatus sacculifer, $334 \mathrm{bp}$ for Globigerinella siphonifera, $373 \mathrm{bp}$ for Neogloboquadrina dutertrei and 413 to $420 \mathrm{bp}$ for Globigerinita glutinata. For the $37 \mathrm{~F}$ region the fragment sizes were $212 \mathrm{bp}$ for $N$. pachyderma and $177 \mathrm{bp}$ for T. sacculifer. Series of 10 -fold dilution from $10^{-1}$ to $10^{-8}$ were prepared and the number of gene copies in each dilution were calculated based on the numbers inferred from the initial PCR product divided by the dilution factor. We retained the dilution from $10^{-3}$ to $10^{-8}$ for each series because the less diluted samples would have been out of the range of the measured samples.

The quality of each dilution series was estimated using an optimized qPCR protocol. The protocol was optimized to use consumables conservatively while retaining maximum reproducibility of the results. We used the PowerTrack SYBR Green Master Mix (ThermoFisher Scientific) and used the following mix: $0.25 \mu \mathrm{l}$ of Yellow Sample Buffer, $5 \mu \mathrm{l}$ of PowerTrack SYBR Green Master Mix, $0.25 \mu \mathrm{l}$ of forward and reverse primer $\left(10 \mathrm{ng} \mathrm{\mu l}^{-1}\right), 3.25 \mu \mathrm{l}$ of nuclease-free Milli-Q water and $1 \mu$ l of DNA template to a final volume of $10 \mu \mathrm{l}$. The $\mathrm{gPCR}$ was performed with the QuantStudio 1 Real-Time PCR thermocycler (Applied Biosystems, Thermo Fisher Scientific) 
with the following steps: initial denaturation at $95^{\circ} \mathrm{C}$ for $2 \mathrm{~min}$ followed by 40 cycles of denaturation at $95^{\circ} \mathrm{C}$ for $15 \mathrm{~s}$ and annealing-extension at $60^{\circ} \mathrm{C}$ for $1 \mathrm{~min}$ and final Melt Curve Stage where the temperature ramped up from $60^{\circ} \mathrm{C}$ to $95^{\circ} \mathrm{C}$ increasing by $1{ }^{\circ} \mathrm{C}$ every $0.15 \mathrm{~s}$. We retained as standard curves those having a $R^{2}$ equal or above 0.99 , a single peak in the melt curve plot and an efficiency between $90 \%$ and $110 \%$.

\section{qPCR and final validation}

After validation of the standard curves, all positive extractions were quantified with the following approach. Each qPCR session included only standards and samples belonging to the same species and marker, where samples and standards were loaded in triplicates to quantify experimental error, and every session included negative controls of extractions and negative PCR controls. The same optimized protocol presented above was used for every species and marker. After the end of the reaction, one triplicate of each sample and the negative controls were migrated to confirm that only a single fragment of the expected length was amplified in each reaction. As a final confirmation that the right target and species has been successfully amplified, another triplicate was purified with QIAquick PCR purification kit (QIAGEN) and sequenced by an external provider (LGC Genomics, Berlin). The obtained sequences were compared to the $\mathrm{PFR}^{2}$ database and in case the amplified product was not belonging to the expected target, the data was discarded. Because of their short length and limited use outside of the purpose of this study, the sequences are provided as part of Supplementary Information but not deposited on NCBI.

\section{Data analyses}

Prior to downstream analyses, the data were evaluated to exclude potentially inaccurate quantifications. We excluded quantifications where one replicate showed a significant deviation from the two other (automatically detected by the QuantStudio 1). Then, the gene copy numbers quantified in every reaction were multiplied by 50 to calculate the number of gene copies in every foraminifera cell (As $1 \mu$ l of DNA extract was used from the $50 \mu \mathrm{l}$ of the entire extraction where each cell was dissolved). Next, the minimal number of gene copies per reaction was set to 100 copies, which would mean that there were at least 2 copies per $1 \mu \mathrm{l}$ of DNA template, to prevent usage of single cell amplification results that are too close to the lower detection limit of the thermocycler. Quantification data are provided in Supplementary Information.

After data curation, the first analysis consisted in evaluating the congruence between quantifications made on the $37 \mathrm{~F}$ and $45 \mathrm{E}-47 \mathrm{~F}$ on specimens of $N$. pachyderma and $T$. sacculifer with a linear regression (Fig. 1). Next, we evaluated if a significant difference exists in gene copy number between species of foraminifera for individual cells (Fig. 2A, B), or between number of copies per unit of volume (gene copy numbers per $\mathrm{mm}^{3}$, Fig. $2 \mathrm{C}, \mathrm{D}$ ). An initial Shapiro-Wilk normality test performed on the raw data concluded that they did not follow a normal distribution (Table S1). The data were logarithmically transformed, which led to normalization of the distribution of the values for both quantification (gene copy number per specimens and per unit of volume) and markers considering all data points or individual species values except for $T$. sacculifer when considering unit volume ( $p$-value $=0.019$ ). We considered this as a minor deviation from normal distribution and proceeded with a one-way ANOVA (Table S2) to test for difference in means and applied a post-hoc pairwise t-test (Table S3) when the results of the ANOVA were significant. Finally, we used two complementary approaches to test for the relationship between size and number of gene copy. We ran a Two-way ANOVA to test for the interaction between size and number of gene copy (Table S4) in parallel with linear regressions between sizes of individual specimens and the number of gene copies for both markers and individual species (Fig. 3).

\section{Comparison with previous results and model}

We used a modelling approach to assess the compatibility of our results with those obtained on three benthic foraminifera species by [32]. In that study, the average number of gene copies extracted from a pool of ten specimens was quantified twice for each benthic foraminifera species. To obtain comparable results, we simulated for each species 100 random samplings of a pool of ten specimens to infer the theoretical number of gene copy that we would have obtained with a pooled approach. The gene copy number of an individual in the simulation was selected randomly (with replacement) from the observed distributions of single-cell

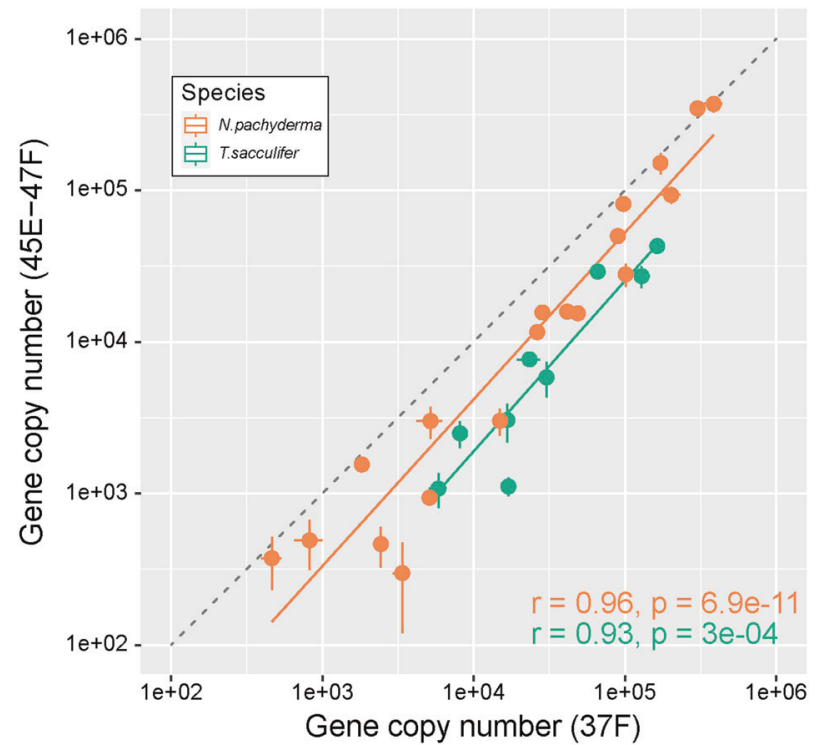

Fig. 1 Linear regression between quantification of gene copy number made with the marker $37 \mathrm{~F}$ and $45 \mathrm{E}-47 \mathrm{~F}$ on same specimens of the species Neogloboquadrina pachyderma and Trilobatus sacculifer. Each dot represents the average of triplicated quantification and the vertical and horizontal lines represent the standard deviation of the measurements. The dashed line indicates the expected 1:1 relationship and the inferred relationships are offset towards higher quantification by the $37 \mathrm{~F}$ region.

quantifications for each species (Fig. 2).The result of this simulation is shown on Fig. 4 together with the results of [32] for direct comparison.

Next, we assessed the potential impact of the difference in average copy number between species and the large variability in number of gene copy between specimens on metabarcoding datasets. For simplicity, we simulated a theoretical population where the five species for which we have data would occur in equal proportions, and considered a population size of 50, 100, 250, 500 and 1000 specimens. We conducted 100 random samplings for each population size and calculated the theoretical relative proportions derived from a metabarcoding dataset, and with and without the application of a normalisation factor. We calculated the normalisation factor by dividing the average number of gene copy of all species by the lowest average number of gene copy (Fig. 4). All data analyses and models were performed in R [38] using ggplot2 [39] and tidyverse [40]. All data presented in the paper were made available at PANGAEA.

\section{RESULTS}

We successfully quantified gene copy number of 139 specimens (18 to 45 specimens per species), and for 28 specimens we obtained the gene copy number for both markers $37 \mathrm{~F}$ and $45 \mathrm{E}-47 \mathrm{~F}$ (Fig. 1). Comparison of the results between the two markers revealed a high correlation $(r>0.9)$ for both $T$. sacculifer and $N$. pachyderma, but with an offset from the expected 1:1 line (Fig. 1). Quantifications made with the longer fragment 45E-47F systematically yielded lower number of copies but conserved the scalability across the full range of the observed gene copy number variation. Since the $45 \mathrm{E}-47 \mathrm{~F}$ marker provides better taxonomic coverage and resolution, allowing metabarcoding of all the analysed species with the same primer pair, we chose to do the remaining quantifications with the $45 \mathrm{E}-47 \mathrm{~F}$ marker. Using this marker the average number of gene copies per species varied from $\sim 4000$ copies in G. glutinata to $\sim 50,000$ copies in $N$. pachyderma. Within species, the variability was larger, ranging between 370,000 copies observed in a single specimen of $N$. pachyderma down to less than 1000 copies observed in seven specimens of this species (Fig. 2C). A similarly large variability was observed for $N$. dutertrei and T. sacculifer, and for G. siphonifera and 

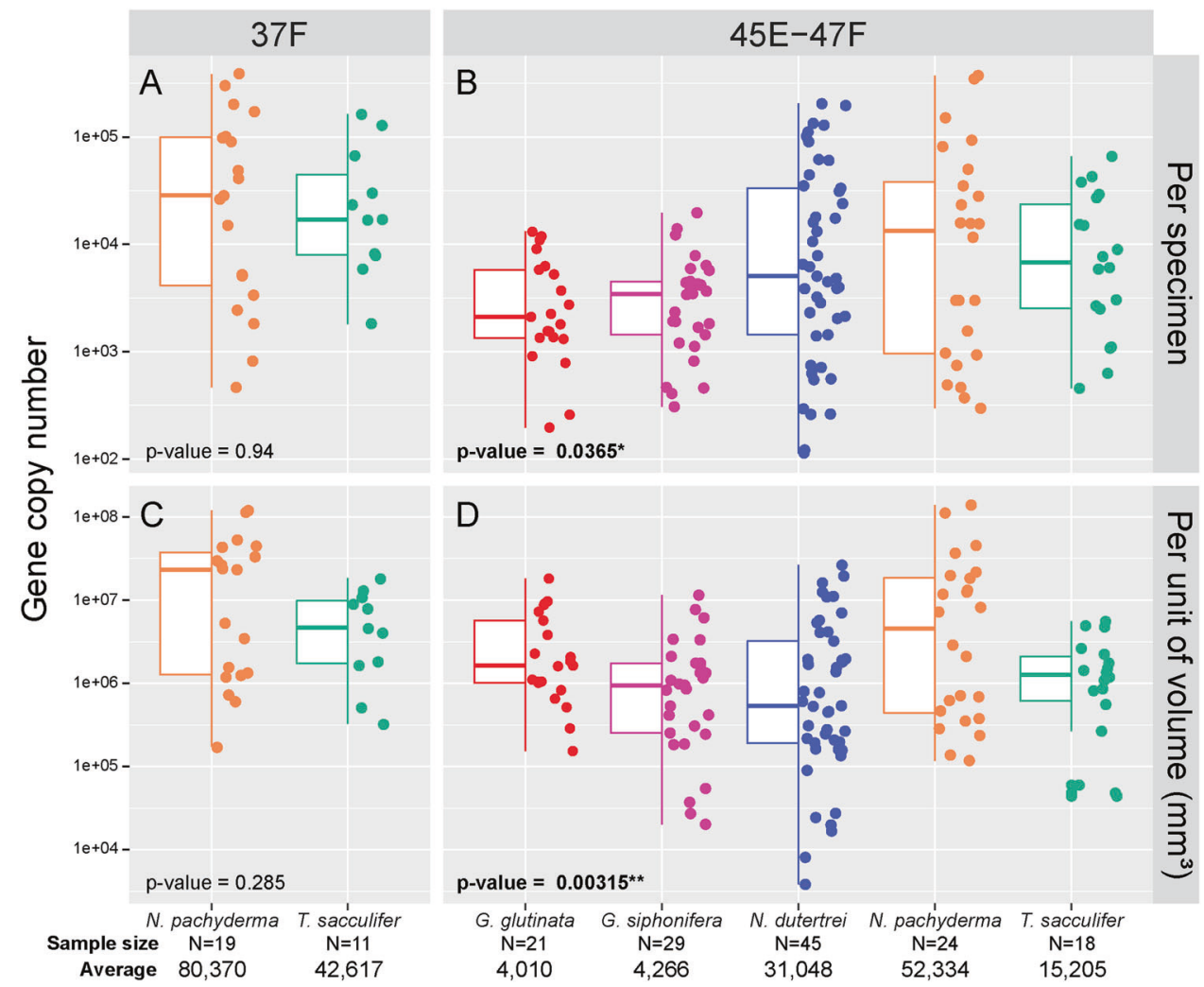

Fig. 2 Gene copy number for the gene markers $37 \mathrm{~F}$ and 45E-47F. Box plot and jitter plot of gene copy number per specimens (A, B) and per unit of volume (C, D) made for both markers. The number of observations per species and average gene copy number per specimen are provided below the graphs. The $p$ values indicate the ANOVA results and the significant results are shown in bold with the number of asterisk giving the level of significance.

G. glutinata that had an average gene copy number of $\sim 4000$, where the single-specimens values varied between $\sim 200$ and $\sim 11,000$ copies and $\sim 300$ and $\sim 19,000$ copies respectively. Hence, we observed a difference of one order of magnitude in average copy number among species, but a difference of more than two orders of magnitude among specimens belonging to the same species.

The ANOVA applied to the number of gene copies per specimen revealed significant differences when considering all species (Fig. 2, Table S2) but the pairwise comparisons showed that there only some species pairs show significant differences. Specifically, there is no significant difference between G. glutinata and $G$. siphonifera on the one hand, and between $N$. dutertrei, $N$. pachyderma and T. sacculifer on the other hand (Table S3). The same analyses applied on the number of gene copies per unit of volume (considering the actual cell volumes of the analysed specimens) returned a different picture with $N$. pachyderma being significantly different from all species except of G. glutinata, and G. glutinata being significantly different from $G$. siphonifera and $N$. dutertrei (Table S3). A significant relationship between gene copy number and cell volume appeared neither among all specimens, nor within specimens of the same species (Fig. 3), and the Twoway ANOVA also returned a non-significant $p$ value for the interaction between these two factors (Table S4). Most of the relationships were positive, none of the linear regression explained more than $16 \%$ of the variance and none of the correlation coefficients were significant (Fig. 3). The results obtained with the $37 \mathrm{~F}$ marker were consistent with those obtained with the $45 \mathrm{E}-47 \mathrm{~F}$.

To connect the obtained results with the previous study by [32], we artificially pooled results from ten individuals that were quantified separately, using 100 random iterations. This approach reduced the variability such that not only the mean values of gene copy number per specimen, but also the differences among the replicates match the range of gene copy numbers observed by [32] in the benthic species Allogromia, Bolivina and Rosalina (Fig. 4).

Next, using the observed magnitude of variability and observed mean gene copy number per species, we simulated metabarcoding results for a community containing the five studied species in equal proportion of individuals (Fig. 5). Modelling the effect of gene copy number variability and the average revealed that the relative proportions of each species in a metabarcoding community would strongly deviate from their "true" proportions, even where large populations were sampled (Fig. 5). Interestingly, under this configuration, species with the lowest average gene copy number (G. glutinata and $G$. siphonifera) would be consistently recorded as rare, even with the smallest sampled populations. By applying a correction factor based on average gene copy number per species, the metabarcoding community composition can be brought closer to the real proportions, provided enough (in this case at least 500-1000) specimens have been sampled. Applying the correcting factor equalizes the variability among the species, and the variability overall decreases systematically with increased population size.

\section{DISCUSSION}

Our results imply a remarkable extent of variability in gene copy number, spanning more than two orders of magnitude, within five species of planktonic foraminifera. We also show that only a small part of this variability could be explained by differences in cell volume (Fig. 3) and we did not find any evidence for a significant interaction between size and gene copy number either (Table S4). 


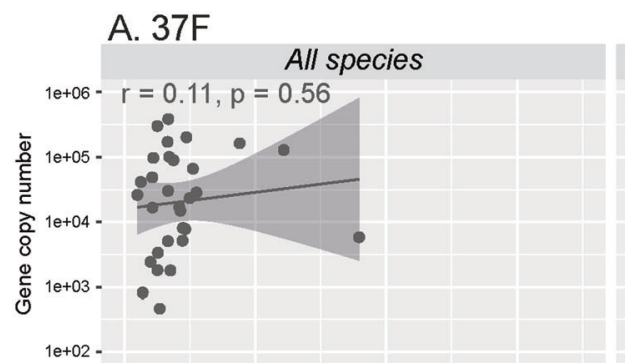

B. $45 \mathrm{E}-47 \mathrm{~F}$

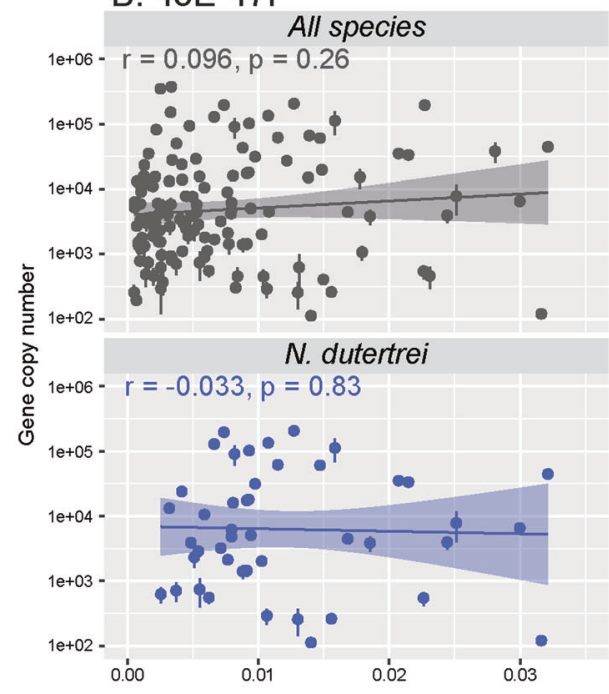

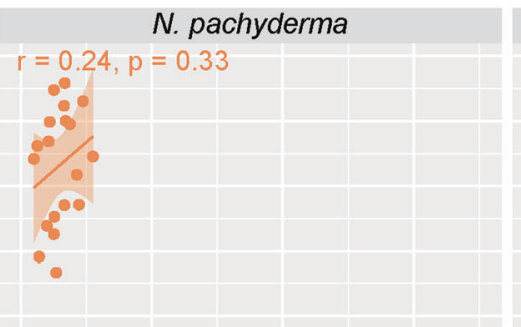

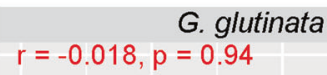

$r=-0.018, p=0.94$
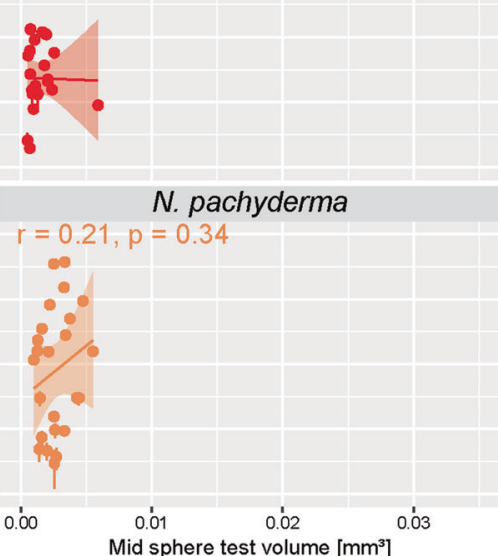
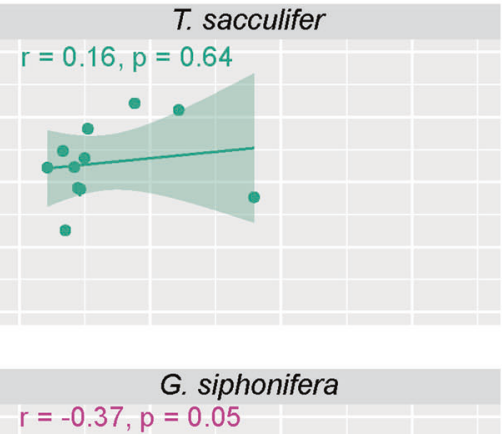

$r=-0.37, p=0.05$
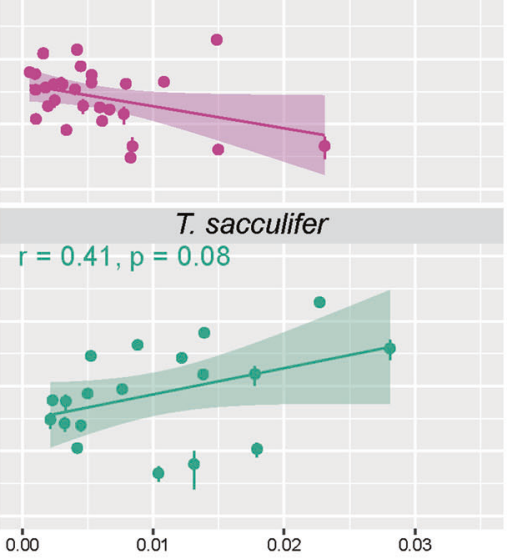

Fig. 3 Linear regression between gene copy number and volume of individual cell for all measurements and per species. The correlation coefficient $r$ and associated $p$ values are provided for each graph.
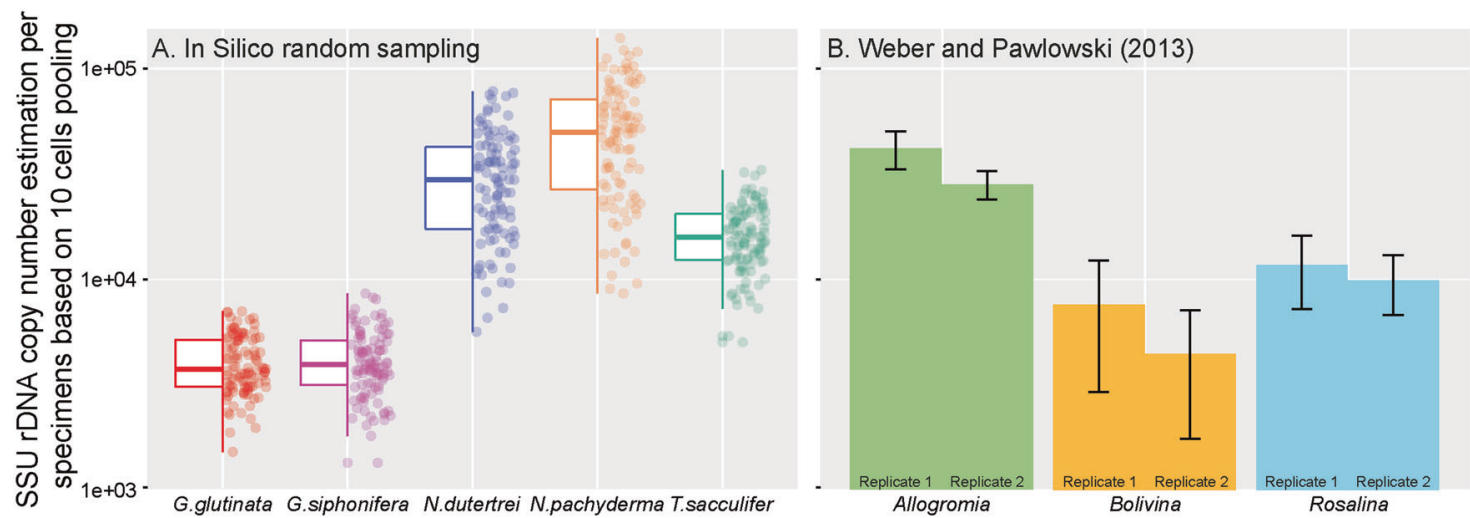

Fig. 4 Gene copy number estimation with pooling of ten specimens. Comparison between the results of (A) this study and the results (B) of Weber and Pawlowski (2013) obtained from duplicated quantification of gene copy number of three species of benthic foraminifera based on DNA extraction of pooled specimens $(N=10)$. We performed 100 random in silico resampling of ten values obtained on single specimen.

To our knowledge, this is the first demonstration of such an extent of variability among specimens of the same species. Previous studies were based on small number of replicates and although they documented large difference among species, they attributed the observed differences within species to technical bias $[15,18]$. Considering the congruence between the two independent markers (Fig. 1), the observed range in gene copy numbers in our study cannot be explained by technical issues. We especially note that the direction of the observed offset between the two markers is consistent with observations that longer fragments yield lower number of copies in qPCR analyses [41]. Nonetheless, before interpreting the large variability as a primary biological signal, we consider potential other sources of bias. Having excluded technical bias of the qPCR, the only other plausible source of bias is the possibility that some of the low values observed could have been due to partial degradation of DNA in some of the analysed specimens. Ideally, for the qPCR method, the DNA should be extracted from freshly collected specimens. However, planktonic foraminifera are difficult to maintain in culture and can only be collected from the pelagic environment, which is why we analysed cryopreserved individuals from our collection [34]. Because we worked with cryopreserved specimens that had to be repeatedly manipulated for separation and then for imaging and $\mathrm{qPCR}$, it is possible that the DNA could have been partly degraded, resulting in apparent lower number of gene. However, we note the mean gene copy number per species in our 


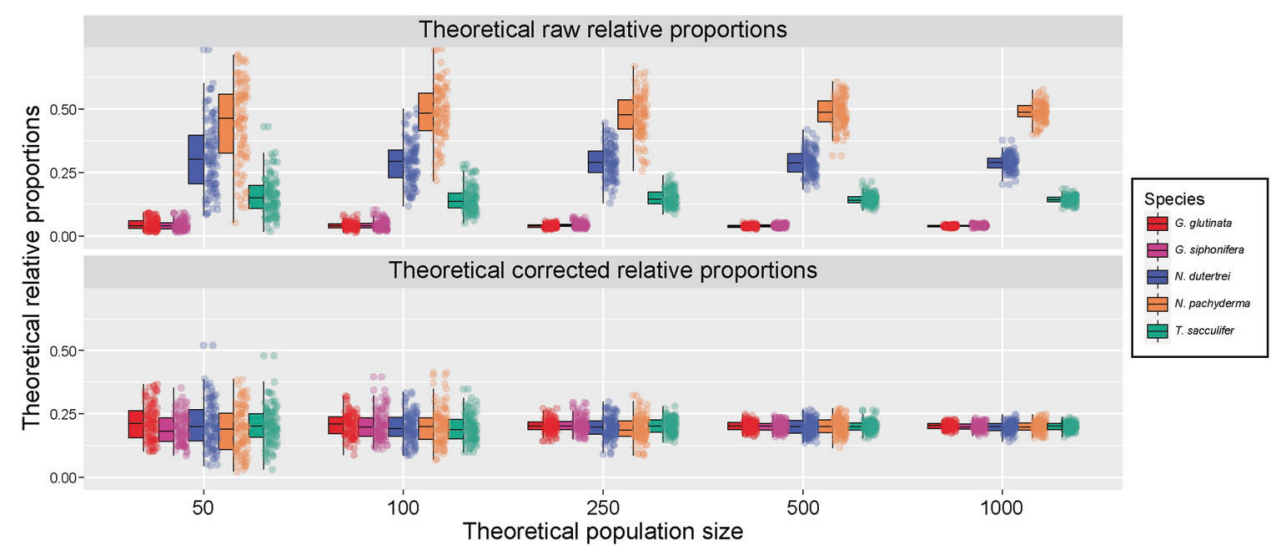

Fig. 5 Modeling of the potential effect of gene copy number variability on metabarcoding datasets. We modelled a theoretical population where all species would occur in equal proportions, simulated five population sizes and performed 100 random samplings of the measured gene copy number and calculated the relative proportions. We applied a normalization factor on the resulting proportions to correct the difference in gene copy number to assess the impact of the variability only.

analyses are comparable with those of [32], who worked with living cultures (Fig. 4). If our analyses were affected by DNA degradation, the average gene copy numbers should have been lower. Hence, it is unlikely that preservation issues may have significantly affected the overall results.

Since the per species gene copy numbers are comparable to previous studies [32] and fall within the range of variability of eukaryotes, when scaled to cell volume [5], we must conclude that the observed variability reflects genuine biological differences among the sampled specimens, and that the largest part of this variability cannot be explained by differences in cell volume (Fig. 3). Our estimation of planktonic foraminifera cell is biased by two factors, the extrapolation of the measured tests semi-volume one the one hand and episodic growth in the other hand. Since all investigated species of foraminifera have a roughly comparable test morphology (trochospiral or planispiral with lobate chambers) the applied method of full test volume approximation will have affected the volume data for all species in a very similar way and did not affect the relationship between volume and gene copy number. Planktonic foraminifera grow their shells episodically by adding successive chambers [42]. Since their cell volume increases continuously, there will always be an offset between test and cell volume at any time. However, the size of this offset is unlikely larger than the volume of the terminal chamber, which would correspond among the studied species to differences smaller than a factor of two (volume of the last chamber compared to the remaining part of the shell [43]). The differences between the volume estimation and true cell volume are therefore unlikely to explain the two orders of magnitude variability in gene copy number.

Searching for other potential mechanisms explaining the variability, we note that when normalised to cell volume, the two species $G$. glutinata and N. pachyderma contain more gene copies than the other three species. Gong et al. (2013) suggested that there could be a positive relationship between SSU rDNA gene copy number in ciliates and the amount of intra individual variability in the gene. Both G. glutinata and N. pachyderma have extensive intragenomic variability in the SSU rDNA gene [26, 44], while G. siphonifera and $T$. sacculifer do not [24]. This observation points at gene conversion or a similar process occurring during replication that could lead to disproportionately large variability and number of gene copies within individual genomes. Along the similar line, we note that protists genomes are dynamic and undergo important modifications during their individual life cycles of [45]. Foraminifera are multinucleated and heterokaryotic, indicating differential genome multiplication during life, which is episodic [46], thus likely contributing to gene copy number variability per specimen in a way similar as the cell volume size bias due to episodic chamber addition as described above. However, it has also been shown experimentally that food source may influence the nuclear size and DNA content of foraminifera [47], akin to a process by which phytoplankton is able to modify its elemental stoichiometry [48]. Furthermore, prior to reproduction, the nucleus of foraminifera enlarges and DNA and other material condense into granules that are degraded in a process referred as Zerfall [49], allowing the foraminifera to reduce their genome back to the reproductive size [46]. During this process, the number of gene copies is likely modified and "resets" the gene copy number to a state that is independent of cell size. Finally, foraminifera can reproduce sexually or asexually $[50,51]$. It results in offspring of different ploidy and likely genome organisation, potentially producing another dimension of variability in gene copy number per individual. We observe that the distribution of gene copy number seems to follow a bimodal distribution in N. pachyderma (Fig. 2) where asexual reproduction has been observed [50], and it could reflect expression of the diploid and haploid phases.

Although the process (or processes) controlling the variation in gene copy number in foraminifera remain elusive, the large inter individual variability we observe highlights the fact that the mentioned and further, probably unknown, cellular processes are the primary source of bias in metabarcoding studies. Our simulations indicate that the effect is greater for smaller populations (Fig. 5). Planktonic foraminifera populations are denser in the upper $100 \mathrm{~m}$ of the water column compared with the deeper aphotic zone, with $>100$ specimens per $\mathrm{m}^{3}$ in tropical and subtropical waters [52-54]. A typical depth-stratified collection of planktonic foraminifera using a multiple closing plankton net collects between five $\mathrm{m}^{3}$ of water in the surface layer and $50 \mathrm{~m}^{3}$ in the deeper layer where the population is sparse and thus recovers from a few to several hundred specimens. It is only in upwelling regions or in the highly productive temperate to subpolar areas where more than a thousand specimens would be collected at once [55]. This means that a large portion of environmental samples, especially those derived from oligotrophic regions or taken from the subsurface layer of the ocean will be affected by gene copy number variability, even when corrected for average values per species. Conversely, where the sampled populations are large, containing hundreds or even thousands of specimens (Fig. 5), the empirically derived correction factors would likely mitigate the bias due to gene copy number variation. Using a different approach [20], also showed that an in silico correction of gene copy number would affect estimates of compositionality in marine phytoplankton. Collectively, these results imply that the composition of metabarcoding, but also metagenomic, datasets can be brought 
closer to ecological proportionality, but due to the observed variability in gene copy number among individuals, this requires sampling of large populations.

\section{CONCLUSION}

The large inter individual variability and difference in average SSU rDNA gene copy number between species of planktonic foraminifera challenges the application of metabarcoding approaches to assess community composition. Although metabarcoding offers great advantages such as covering the entire diversity in a sample including its cryptic component, the compositionality of the dataset may not reflect the actual living community in neither relative abundance or biomass. Deriving correction factors based on single-cell (or single individual) quantification or coupling metabarcoding with high-throughput imaging [56] appear to be potential avenues to characterize accurately living communities. Irrespective of this applied issue, our results highlight the dynamic nature of the foraminifera genome and hints to yet unknown cellular processes resulting in the previously unknown and unexpectedly high degree of variability in gene copy numbers among specimens of same species.

\section{REFERENCES}

1. Pyron M. Characterizing communities. Nat Educ Knowl. 2010;3:39.

2. Hatton IA, Heneghan RF, Bar-On YM, Galbraith ED The global ocean sizespectrum from bacteria to whales. bioRxiv 2021; 2021.04.03.438320.

3. Karsenti E, Acinas SG, Bork P, Bowler C, De Vargas C, Raes J, et al. A holistic approach to marine Eco-systems biology. PLoS Biol. 2011;9:e1001177.

4. Mora C, Tittensor DP, Adl S, Simpson AGB, Worm B. How many species are there on Earth and in the ocean? PLoS Biol. 2011;9:e1001127.

5. de Vargas C, Audic S, Henry N, Decelle J, Mahé F, Logares R, et al. Eukaryotic plankton diversity in the sunlit ocean. Science. 2015;348:1-12.

6. Lejzerowicz F, Gooday AJ, Barrenechea Angeles I, Cordier, T, Morard, R, Apothéloz-Perret-Gentil $\mathrm{L}$, et al. Eukaryotic biodiversity and spatial patterns in the Clarion-Clipperton zone and other abyssal regions: insights from sediment DNA and RNA metabarcoding. Front Mar Sci. 2021;8:1-23.

7. Mahé F, de Vargas C, Bass D, Czech L, Stamatakis A, Lara E, et al. Parasites dominate hyperdiverse soil protist communities in Neotropical rainforests. Nat Ecol Evol. 2017;1:1-8

8. Pawlowski J, Kelly-Quinn M, Altermatt F, Apothéloz-Perret-Gentil L, Beja P, Boggero $A$, et al. The future of biotic indices in the ecogenomic era: Integrating (e) DNA metabarcoding in biological assessment of aquatic ecosystems. Sci Total Environ. 2018:637-638:1295-310.

9. Ruppert KM, Kline RJ, Rahman MS. Past, present, and future perspectives of environmental DNA (eDNA) metabarcoding: A systematic review in methods, monitoring, and applications of global eDNA. Glob Ecol Conserv. 2019;17:e00547.

10. Zinger L, Bonin A, Alsos IG, Bálint M, Bik H, Boyer F, et al. DNA metabarcodingNeed for robust experimental designs to draw sound ecological conclusions. Mol Ecol. 2019;28:1857-62.

11. Lamb PD, Hunter E, Pinnegar JK, Creer S, Davies RG, Taylor MI. How quantitative is metabarcoding: A meta-analytical approach. Mol Ecol. 2019;28:420-30.

12. del Campo J, Kolisko M, Boscaro V, Santoferrara LF, Nenarokov S, Massana R, et al. EukRef: Phylogenetic curation of ribosomal RNA to enhance understanding of eukaryotic diversity and distribution. PLoS Biol. 2018;16:e2005849.

13. Guillou L, Bachar D, Audic S, Bass D, Berney C, Bittner L, et al. The Protist Ribosomal Reference database (PR2): a catalog of unicellular eukaryote small sub-unit rRNA sequences with curated taxonomy. Nucleic Acids Res. 2013;41:D597-D604.

14. Godhe A, Asplund ME, Härnström K, Saravanan V, Tyagi A, Karunasagar I. Quantification of diatom and dinoflagellate biomasses in coastal marine seawater samples by real-time PCR. Appl Environ Microbiol. 2008;74:7174-82.

15. Gong J, Dong J, Liu X, Massana R. Extremely high copy numbers and polymorphisms of the rDNA operon estimated from single cell analysis of oligotrich and peritrich ciliates. Protist. 2013:164:369-79.

16. Rodríguez-Martínez R, Labrenz M, del Campo J, Forn I, Jürgens K, Massana R. Distribution of the uncultured protist MAST-4 in the Indian Ocean, Drake Passage and Mediterranean Sea assessed by real-time quantitative PCR. Environ Microbiol. 2009;11:397-408.
17. Zhu F, Massana R, Not F, Marie D, Vaulot D. Mapping of picoeucaryotes in marine ecosystems with quantitative PCR of the 18S rRNA gene. FEMS Microbiol Ecol. 2005;52:79-92.

18. Wang Y, Jiang Y, Liu Y, Li Y, Katz LA, Gao F, et al. Comparative studies on the polymorphism and copy number variation of mtSSU rDNA in ciliates (Protista, ciliophora): Implications for phylogenetic, environmental, and ecological research. Microorganisms. 2020;8:316.

19. Dunthorn M, Stoeck T, Clamp J, Warren A, Mahé F. Ciliates and the rare biosphere: A review. J Eukaryot Microbiol. 2014;61:404-9.

20. Gong W, Marchetti A. Estimation of $18 \mathrm{~S}$ gene copy number in marine eukaryotic plankton using a next-generation sequencing approach. Front Mar Sci. 2019;6:1-5.

21. Kucera M. Chapter six planktonic foraminifera as tracers of past oceanic environments. Dev Mar Geol. 2007;1:213-62.

22. Morard R, Escarguel G, Weiner AK, André A, Douady CJ, Wade CM, et al. Nomenclature for the nameless: a proposal for an integrative molecular taxonomy of cryptic diversity exemplified by planktonic foraminifera. Syst Biol. 2016;65:925-40.

23. Darling KF, Wade CM. The genetic diversity of planktic foraminifera and the global distribution of ribosomal RNA genotypes. Mar Micropaleontol. 2008;67:216-38.

24. André A, Quillévéré $F$, Morard R, Ujiié $Y$, Escarguel $G$, de Vargas $C$, et al. SSU rDNA divergence in planktonic foraminifera: molecular taxonomy and biogeographic implications. PLoS ONE. 2014;9:e104641.

25. Morard R, Garet-Delmas MJ, Mahé F, Romac S, Poulain J, Kucera M, et al. Surface ocean metabarcoding confirms limited diversity in planktonic foraminifera but reveals unknown hyper-abundant lineages. Sci Rep. 2018;8:1-10. 2539

26. Morard R, Vollmar NM, Greco M, Kucera M. Unassigned diversity of planktonic foraminifera from environmental sequencing revealed as known but neglected species. PLoS One. 2019;14:e0213936.

27. Lecroq B, Lejzerowicz F, Bachar D, Christen R, Esling P, Baerlocher L, et al. Ultradeep sequencing of foraminiferal microbarcodes unveils hidden richness of early monothalamous lineages in deep-sea sediments. Proc Natl Acad Sci U S A. 2011;108:13177-82.

28. Lejzerowicz F, Esling P, Pawlowski J. Patchiness of deep-sea benthic Foraminifera across the Southern Ocean: Insights from high-throughput DNA sequencing. Deep Sea Res Part II Top Stud Oceanogr. 2014;108:17-26.

29. Shi J, Lei Y, Li Q, Lyu M, Li T. Molecular diversity and spatial distribution of benthic foraminifera of the seamounts and adjacent abyssal plains in the tropical Western Pacific Ocean. Mar Micropaleontol. 2020;156:101850.

30. Li Q, Lei Y, Morard R, Li T, Wang B. Diversity hotspot and unique community structure of foraminifera in the world's deepest marine blue hole-Sansha Yongle Blue Hole. Sci Rep. 2020;10:10257.

31. Cordier T, Barrenechea I, Lejzerowicz F, Reo E, Pawlowski J. Benthic foraminiferal DNA metabarcodes significantly vary along a gradient from abyssal to hadal depths and between each side of the Kuril-Kamchatka trench. Prog Oceanogr. 2019;178:102175.

32. Weber AA-T, Pawlowski J. Can Abundance of Protists Be Inferred from Sequence Data: A Case Study of Foraminifera. PLoS One. 2013;8:e56739.

33. Jonkers $L$, Meilland J, Rillo MC, de Garidel-Thoron T, Kitchener JA, Kucera M. Linking zooplankton time series to the fossil record. ICES J Mar Sci. 2021:1-8.

34. Weiner AKM, Morard R, Weinkauf MFG, Darling KF, André A, Quillévéré $F$, et al. Methodology for single-cell genetic analysis of planktonic foraminifera for studies of protist diversity and evolution. Front Mar Sci. 2016;3:1-15.

35. Arya M, Shergill IS, Williamson M, Gommersall L, Arya N, Patel HR. Basic principles of real-time quantitative PCR. Expert Rev Mol Diagn. 2005;5:209-19.

36. Barrenechea Angeles I, Lejzerowicz F, Cordier T, Scheplitz J, Kucera M, Ariztegui D, et al. Planktonic foraminifera eDNA signature deposited on the seafloor remains preserved after burial in marine sediments. Sci Rep. 2020;10:1-12.

37. Morard R, Darling KF, Mahé F, Audic S, Ujiié Y, Weiner AK, et al. PFR ${ }^{2}$ : a curated database of planktonic foraminifera $18 \mathrm{~S}$ ribosomal DNA as a resource for studies of plankton ecology, biogeography and evolution. Mol Ecol Resour. 2015;15:1472-85.

38. R Development Core Team. R: A language and environment for statistical computing. R Foundation for Statistical Computing. http://www.r-project.org/.

39. Wickham H ggplot2: Elegant graphics for data analysis. 2009. Springer-Verlag, New York.

40. Wickham H, Averick M, Bryan J, Chang W, McGowan L, François R, et al. Welcome to the Tidyverse. J Open Source Softw. 2019;4:1686.

41. Debode F, Marien A, Janssen É, Bragard C, Berben G. The influence of amplicon length on real-time PCR results. Biotechnol Agron Soc Environ. 2017;21:3-11.

42. Bé AWH, Lott L. Shell growth and structure of planktonic foraminifera. Science. 1964;145:2-3.

43. Caromel AGM, Schmidt DN, Fletcher I, Rayfield EJ Morphological change during the ontogeny of the planktic foraminifera. J Micropalaeontology. 2015; 2014-017.

44. Darling KF, Kucera M, Kroon D, Wade CM. A resolution for the coiling direction paradox in Neogloboquadrina pachyderma. Paleoceanography. 2006;21:PA2011-n/a. 
45. Parfrey LW, Lahr DJG, Katz LA. The dynamic nature of eukaryotic genomes. Mol Biol Evol. 2008;25:787-94.

46. Parfrey LW, Katz LA. Dynamic genomes of eukaryotes and the maintenance of genomic integrity. Microbe. 2010;5:156-63.

47. Parfrey LW, Katz LA. Genome dynamics are influenced by food source in Allogromia laticollaris strain CSH (Foraminifera). Genome Biol Evol. 2010;2:678-85.

48. Finkel ZV, Beardall J, Flynn KJ, Quigg A, Rees TAV, Raven JA. Phytoplankton in a changing world: Cell size and elemental stoichiometry. J Plankton Res. 2010;32:119-37.

49. Goldstein ST. Gametogenesis and the antiquity of reproductive pattern in the Foraminiferida. J Foraminifer Res. 1997;27:319-28.

50. Davis CV, Livsey CM, Palmer HM, Hull PM, Thomas E, Hill TM, et al. Extensive morphological variability in asexually produced planktic foraminifera. Sci Adv. 2020;6:1-8.

51. Takagi $H$, Kurasawa A, Kimoto K. Observation of asexual reproduction with symbiont transmission in planktonic foraminifera. J Plankton Res. 2020;42:403-10.

52. Lessa D, Morard R, Jonkers L, Venancio IM, Reuter R, Baumeister A, et al. Distribution of planktonic foraminifera in the subtropical South Atlantic: Depth hierarchy of controlling factors. Biogeosciences. 2020;17:4313-42.

53. Kucera M, Michael S, Raphaël M, Lukas J, Christiane S, Philipp M, et al. Scales of Population Dynamics, Ecology and Diversity of Planktonic Foraminifera and their Relationship to Particle Flux in the Eastern Tropical Atlantic: Cruise No. M140, 11.8.2017-5.9.2017, Mindelo (Cabo Verde)-Las Palmas (Spain) - FORAMFLUX. 2019. Bonn.

54. Schiebel R. Planktic foraminiferal sedimentation and the marine calcite budget. Global Biogeochem Cycles. 2002;16:3-1-3-21.

55. Meilland J, Schiebel R, Lo Monaco C, Sanchez S, Howa H. Abundances and test weights of living planktic foraminifers across the Southwest Indian Ocean: implications for carbon fluxes. Deep Sea Res Part I Oceanogr Res Pap. 2018;131:27-40.

56. Pierella Karlusich JJ, Pelletier E, Lombard F, Carsique M, Dvorak E, Colin S, et al. Global distribution patterns of marine nitrogen-fixers by imaging and molecular methods. Nat Commun. 2021;12:4160.

\section{ACKNOWLEDGEMENTS}

We thank all crewmembers and scientists for their help in the collection of planktonic foraminifera during the cruises M113/2, M124, M133 and MsM66. We are thankful to Dr. Cyrille Mathieu for his advises on real-time qPCR methodology, Dr. Christiane Glöckner for her support and assistance during this project and two anonymous referees for their constructive comments. The project was funded by the Max Planck Society (IMPRS of Marine Microbiology) and by the Cluster of Excellence "The Ocean Floor-Earth's Uncharted Interface" funded by the German Research Foundation (DFG).

\section{AUTHOR CONTRIBUTIONS}

TM and NR did the labwork and data acquisition, TM, DR, MS and RM did the data analyses, RM and MK did the study design, funding acquisition and supervision, TM, RM and MK wrote the manuscript and all authors read commented and approved the final manuscript.

\section{FUNDING}

Open Access funding enabled and organized by Projekt DEAL.

\section{COMPETING INTERESTS}

The authors declare no competing interests.

\section{ADDITIONAL INFORMATION}

Supplementary information The online version contains supplementary material available at https://doi.org/10.1038/s43705-021-00067-3.

Correspondence and requests for materials should be addressed to Raphaël Morard.

Reprints and permission information is available at http://www.nature.com/ reprints

Publisher's note Springer Nature remains neutral with regard to jurisdictional claims in published maps and institutional affiliations.

(c) Open Access This article is licensed under a Creative Commons Attribution 4.0 International License, which permits use, sharing, adaptation, distribution and reproduction in any medium or format, as long as you give appropriate credit to the original author(s) and the source, provide a link to the Creative Commons licence, and indicate if changes were made. The images or other third party material in this article are included in the article's Creative Commons licence, unless indicated otherwise in a credit line to the material. If material is not included in the article's Creative Commons licence and your intended use is not permitted by statutory regulation or exceeds the permitted use, you will need to obtain permission directly from the copyright holder. To view a copy of this licence, visit http://creativecommons. org/licenses/by/4.0/.

(c) The Author(s) 2021 